\title{
CYTOTOXICITY AND MODE OF CELL DEATH INDUCED BY TRIPHENYLTIN (IV) COMPOUNDS IN VITRO
}

\author{
${ }^{1}$ Normah Awang, ${ }^{1}$ Zalila Abdul Aziz, ${ }^{2}$ Nurul Farahana Kamaludin and ${ }^{1}$ Kok Meng Chan \\ ${ }^{1}$ Environmental Health and Industrial Safety Programme, \\ ${ }^{2}$ Biomedical Science Programme, School of Diagnostic and Applied Health Sciences, Faculty of Health Sciences, \\ Universiti Kebangsaan Malaysia, Jalan Raja Muda Abdul Aziz, 50300 Kuala Lumpur, Malaysia
}

Received 2014-02-25; Received 2014-03-10; Accepted 2014-03-15

\begin{abstract}
A series of newly synthesized organotin (IV) with $N$-alkyl- $N$-phenyldithiocarbamate ligands namely triphenyltin (IV) ethylphenyldithiocarbamate (compound 1) and triphenyltin (IV) butylphenyldithiocarbamate (compound 2) were assessed for their cytotoxic effect against HT-29 human colon adenocarcinoma cells and human CCD-18Co normal colon cells. The cytotoxicity of these organotins in both cells was assessed using 3-(4,5-dimethylthiazol-2-yl)-2, 5-diphenyltetrazholium bromide (MTT) assay upon $24 \mathrm{~h}$ treatment. Both compounds demonstrated potent cytotoxicity towards HT-29 cells with the $\mathrm{IC}_{50}$ of $0.18 \mu \mathrm{M}$ for compound 1 and $0.20 \mu \mathrm{M}$ for compound 2. Interestingly, compound 1 exhibited lower cytotoxicity towards CCD-18Co with $\mathrm{IC}_{50}$ of $1.55 \mu \mathrm{M}$ whereas no $\mathrm{IC}_{50}$ was detected for compound 2 up to $2 \mu \mathrm{M}$ treatment. The mode of cell death was determined based on the externalization of phosphatidylserine using flow cytometry. Cells treated with compound 1 and compound 2 were mainly viable and the apoptotic cell death was around $10 \%$ which suggests that both compounds induced growth arrest. In conclusion, this study demonstrated that both compounds were selective towards human colorectal cells by giving a strong cytotoxicity to cancer cells and low toxicity towards normal cells. Both compounds were suggested to induce growth arrest in HT-29 cells.
\end{abstract}

Keywords: Cytotoxicity, Apoptosis, Organotin (IV), Dithiocarbamate, HT-29, CCD-18Co

\section{INTRODUCTION}

The world cancer statistic in 2008 has estimated 12.66 million people were diagnosed with cancer. Among all types of cancers, colorectal cancer being the third most commonly diagnosed malignancy. An approximately 1.24 million people were suffered with this type of cancer throughout the year, accounting for 10\% of overall cancer cases Cancer Research UK, 2011. The mortality resulted from cancers were 7.56 million whereby the colorectal cancer was ranked as the fourth most common cause of cancer-related death in 2008 Cancer Research UK, 2011 (Sasaki et al., 2010).

The increase number of human population will proportionally increase theincidence of cancer although the rates of current cancer incidence remain consistent
Cancer Research UK, 2011. Therefore, the effective ways to combat the disease, specifically colorectal cancerare crucially needed and many researchers are currently paying a great attention into this matter. The current treatment used forcolorectal cancers are surgery, chemotherapy, radiation therapy and targeted therapies (Hagan et al., 2013). Taken together, surgery excision remains as a basis for cancer treatment especially at the early stages of colorectal cancer (Hagan et al., 2013). Apart from that, chemotherapy is also recognized as one of the effective method used to treat colorectal cancer patients (Hagan et al., 2013; Tong et al., 2011). Several chemotherapeutic drugs usedin colorectal cancer treatment are 5-Fluorouracil (5-FU), bevacizumab, cetuximab and oxaliplatin (NCI, 2013; Hagan et al., 2013). Among these, 5-FU have been the main options Corresponding Author: Normah Awang, Environmental Health and Industrial Safety Programme, Universiti Kebangsaan Malaysia, Jalan Raja Muda Abdul Aziz, 50300 Kuala Lumpur, Malaysia 
for chemotherapyin patients with stage II, III and IV of colorectal cancer (ACS, 2013).

Unfortunately, the colorectal cancer cells have been identified to become resistance in response to 5-FU treatment. In addition, there were some cases reported the toxicity caused by this drugon normal cells. These have become a major problem to ensure a successful chemotherapy among colorectal cancer patients (Srimuangwong et al., 2012). Therefore, more effective anticancer agents are subjected to be developed in order to treat this type of cancer. Many studies are currently focusing on other alternatives to find the most effective way to enhance the efficacy of 5-FU, as well as to reduce its toxicity towards normal cells (Srimuangwong et al., 2012). Hence, some approaches have been introduced to overcome these problems including the combination of 5FU with other drugs or new compounds (Srimuangwong et al., 2012). On the other hands, the newly synthesized compounds are also suggested as the potential chemotherapy drugs and being investigated worldwide.

The synthesized organotin derivatives have been identified as one of the promising candidates to combat cancers (Alama et al., 2009). They are getting more attentions due to their diverse structures and potent biological activities (Shahzadi et al., 2006). Interestingly, the organotinbiological activities are greatly influenced by their various molecular structures and most of them are generally very toxic even at very low concentrations (Pellerito et al., 2006). Previous studies by (Gielen et al.,
2000; Abdellah et al., 2009) using organotin derivatives had shown a significant cytotoxicity and anticancer properties against various types of human cancerous cells in in vitro studies including HT-29 colon adenocarcinoma cells (Girasolo et al., 2010). All novel organotin (IV) derivatives, with the exception of dimethyltin (IV), showed significant cytotoxicity in HT29 and was suggested to induce cell death via apoptosis (Girasolo et al., 2010). To date, the synthesized diand tri-n-butyltin (IV) carboxylates derivatives against HT-29 colon adenocarcinoma cell line showed a potent anticancer activity via the inhibition of thioredoxin reductase at the micromolar range (Oliveira et al., 2013). These examples demonstrated the organotin (IV) derivatives as apromisingand potent new anticancer drugs that promote a new dimension in anticancer drugs development.

In this study, the in vitro cytotoxicity and the mode of cell death of the newly synthesized organotin (IV) compounds namely triphenyltin (IV) ethylphenyldithiocarbamate (compound 1) and triphenyltin (IV) butylphenyldithiocarbamate (compound 2) were assessed. The chemical structures of both compounds are shown in Fig. 1 and 2. The cytotoxicity of both compounds were done in HT-29 colon adenocarcinoma cells and human CCD-18Co normal colon cells. The observation of cell morphological changes and the mode of cell deathin both cells were carried out.

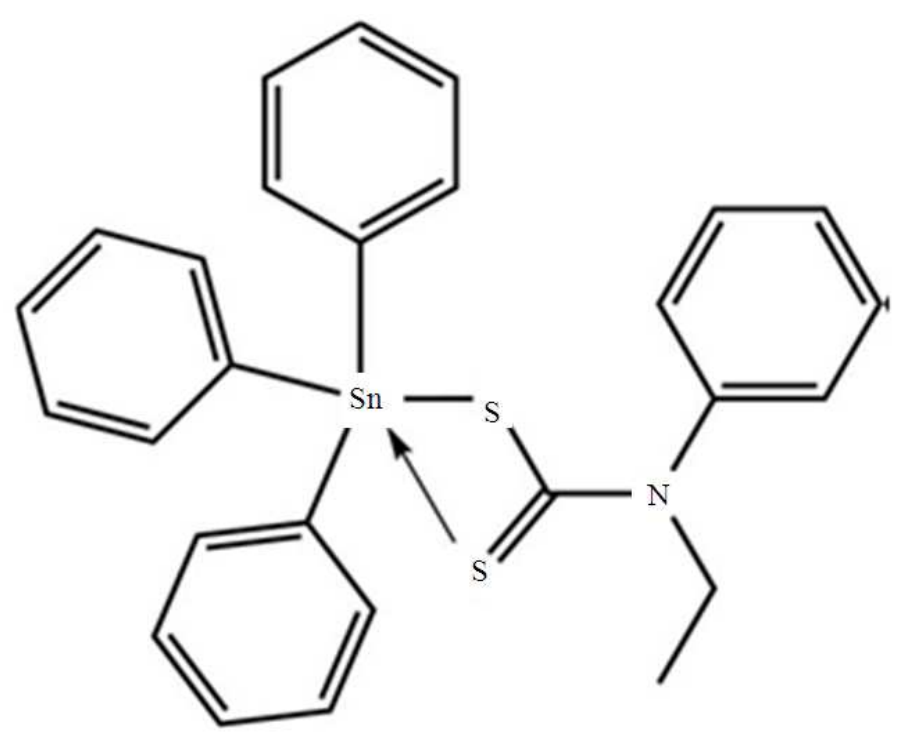

Fig. 1. The chemical structure of compound 1 (Kamaludin et al., 2012) 


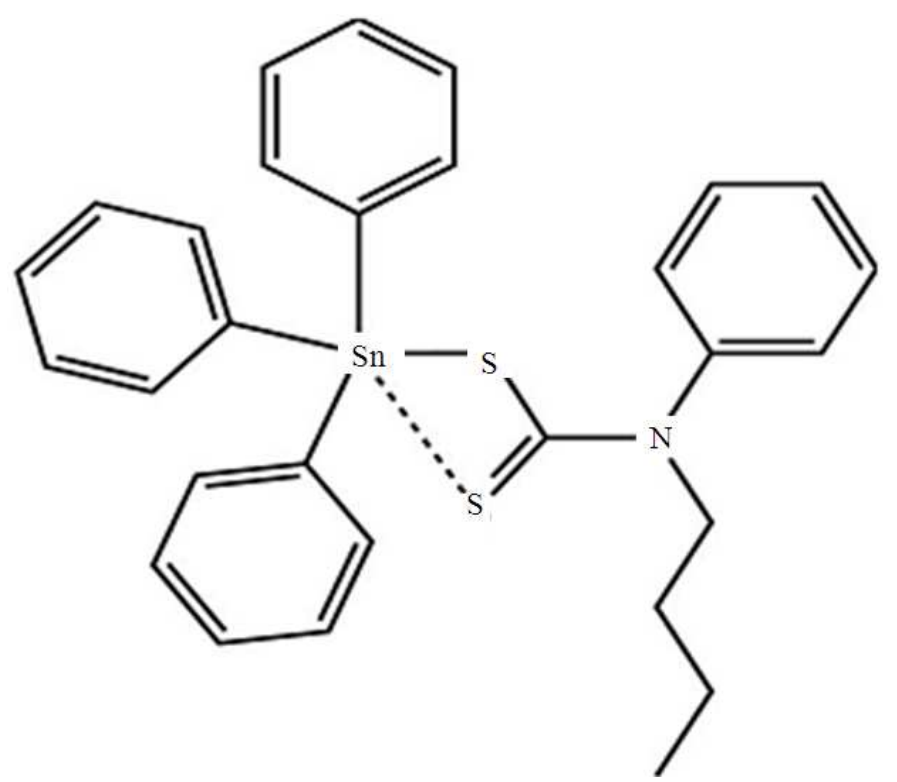

Fig. 2. The chemical structure of compound 2 (Kamaludin et al., 2011)

\section{MATERIALS AND METHODS}

\subsection{Method for Compounds Synthesis}

Both compounds were synthesized via in-situ method using the respective secondary amines, carbon disulphide and triphenyltin (IV) chloride salts. The formation of the compounds were confirmed via elemental analysis $(\mathrm{C}, \mathrm{H}, \mathrm{N}$ and $\mathrm{S}$ ), infrared and nuclear magnetic resonance $\left({ }^{1} \mathrm{H}\right.$ and $\left.{ }^{13} \mathrm{C}\right)$ spectroscopies and X-ray crystallography study (Kamaludin et al., 2011; 2012).

\subsection{Cell Culture and Reagents}

HT-29 human adenocarcinoma cells and human CCD-18Co normal colon cells wereobtained from American Type Culture Collection (ATCC). The HT-29 cells were maintained in McCoy's 5a Modified medium containing L-glutamine and 10\% Foetal Bovine Serum (FBS) (GIBCO, USA). The CCD-18Co cells were maintained in Eagle's Minimum Essential Medium (MEM) supplemented with sodium bicarbonate $\left(\mathrm{NaHCO}_{3}\right), 1 \%$ sodium pyruvate, $1 \%$ non-essential amino acid, 1\% penicillin/streptomycin and 10\% Foetal Bovine Serum (FBS) (GIBCO, USA). The cell lineswere maintained at $37^{\circ} \mathrm{C}$ in $5 \% \mathrm{CO}_{2}$ atmosphere according to the recommended protocols by ATCC.

\subsection{MTT Cytotoxicity Assay}

The viability of HT-29 and CCD-18Co cells were determined using 3-(4,5-dimethylthiazol-2-yl)-2,5- diphenyltetrazholium bromide (MTT) assay (Mosmann, 1983). Cells were seeded in a sterile 96-well microplate at a density of $510^{4}$ cells $\mathrm{mL}^{-1}$ and incubated at $37^{\circ} \mathrm{C}$ in $5 \%$ $\mathrm{CO}_{2}$ for $24 \mathrm{~h}$. Then, the medium in each well was removed and replaced with a fresh medium containing tested compounds at various concentrations ranging from 0 to $2 \mu \mathrm{M}$. After $24 \mathrm{~h}$ of treatment, $20 \mu \mathrm{L}$ of $5 \mathrm{mg} \mathrm{Ml}{ }^{\square 1}$ MTT solution was added to each wellprior to $4 \mathrm{~h}$ incubation.

An approximate of $180 \mu \mathrm{L}$ media in each well was removed and replaced with $180 \mu \mathrm{L}$ of DMSO to dissolve the crystal formazan. After $15 \mathrm{~min}$ of incubation, the plate was agitated using orbital shaker for $5 \mathrm{~min}$ to ensure the crystal formazan was completely dissolved. The Optical Density (OD) of each well was measured at $570 \mathrm{~nm}$ wave length using iMark Microplate Reader (BioRad, USA). The inhibitory concentration that killed $50 \%$ of cell population $\left(\mathrm{IC}_{50}\right)$ was calculated and used as a parameter to compare the relative cytotoxicity of each compound (Thati et al., 2007).

\subsection{Morphological Observation}

Cells were seeded into a sterile 96-well microplate at a density of $5 \times 10^{4}$ cells $\mathrm{mL}^{-1}$ and allowed to attach within $24 \mathrm{~h}$ at $37^{\circ} \mathrm{C}$ in $5 \% \mathrm{CO}_{2}$. Then, the cells were treated with a series of concentrations $(0-2 \mu \mathrm{M})$ for $24 \mathrm{~h}$. Finally, the cells were observed under light inverted microscope at 2000 magnification. 


\subsection{Mode of Cell Death}

Annexin V-FITC/PI test was employed to distinguish between apoptotic and necrotic cells according to the method as previously described by Chan et al. (2012) with slight modifications. The HT29 cells were seeded into a sterile 6 -well microplate at a density of $5 \times 10^{4}$ cells $\mathrm{mL}^{-1}$. After $24 \mathrm{~h}$ of incubation, the cells were treated with both compounds at $\mathrm{IC}_{50}$ concentrations and further incubated for $24 \mathrm{~h}$. Then, the media was collected into a centrifuge tube. The chilled PBS was used to wash the attached cells and it wasalso collected into the tube. The trypsin was added for $1 \mathrm{~min}$ to detach the cells. The trypsinization was stopped using the mediumto prevent cell damages. The cells suspension were collected into the tube. The cells were centrifuged at $220 \mathrm{~g}$ for $5 \mathrm{~min}$. The supernatant was removed. The pellet was washed twice with chilled PBS.Then, the supernatant was discarded and the cells were resuspended in $100 \mu \mathrm{L}$ of Annexin V Binding Buffer. The cells were stained with $2.5 \mu \mathrm{L}$ of Annexin V-FITC (BD Pharmingen) for $15 \mathrm{~min}$ at room temperature. Subsequently, $5 \mu \mathrm{L}$ of Propidium Iodide (PI) $\left(50 \mu \mathrm{g} \mathrm{mL}^{\square 1}\right)$ was added into the cells and further incubated for $2 \mathrm{~min}$. The whole staining process was carried out in dark condition. Further, $400 \mu \mathrm{L}$ of Annexin $\mathrm{V}$ binding buffer was added into the samples and transferred into a Falcon tube. The cells were analysed quantitatively viaBD facscanto II flow cytometry (Becton Dickinson, USA).

\subsection{Selectivity Index (SI)}

The degree of selectivity of the compounds can be expressed by its SI value as suggested by Badisa et al. (2009).

$$
\frac{\mathrm{SI}=\mathrm{IC}_{50} \text { normal }}{\text { cellIC }_{50} \text { cancer cell }}
$$

\subsection{Statistical Analysis}

The data were expressed as the mean \pm Standard Error of Mean (S.E.M). Statistical analysis was performed using Statistical Package for Social Sciences (SPSS) version 17.0 by employing one-way ANOVA. The data wereconsidered statistically significant when $\mathrm{p}<0.05$.

\section{RESULTS}

\subsection{Cytotoxicity of Triphenyltin (IV) $\mathrm{N}$-alkyl- $\mathrm{N}$ - Phenyldithiocarbamate Compounds in HT- 29 and CCD-18Co Cells}

Both compounds showed highcytotoxicity towards HT-29 cellsin concentration dependent manner (Fig. 3).
The $\mathrm{IC}_{50}$ of compound 1 was $0.18 \mu \mathrm{M}$ whereas the $\mathrm{IC}_{50}$ value for compound 2 was $0.20 \mu \mathrm{M}$. This showed that the HT-29 cell line had higher sensitivity towards compound las compared to compound 2. The statistical analysis for both compounds showed significant differences between the percentage of viability of treated and untreated cells $(\mathrm{p}<0.05)$ at all concentrations except $0.031 \mu \mathrm{M}$ and 0.063 $\mu \mathrm{M}$ for compound 1 and compound 2 , respectively.

In contrast to HT-29, only compound 1 gave high cytotoxicity towards CCD-18Co cells with $\mathrm{IC}_{50}$ valueof $1.55 \mu \mathrm{M}$ upon $24 \mathrm{~h}$ of treatment (Fig. 4). There was no $\mathrm{IC}_{50}$ value given by compound 2 up to 2 $\mu \mathrm{M}$ treatment. However, the statistical analysis for compound 1 and 2 showed that the percentage of cell viability for treated cells from $0.25 \mu \mathrm{M}-2.00 \mu \mathrm{M}$ and $0.5 \mu \mathrm{M}-2.00 \mu \mathrm{M}$ were significantly difference $(p<0.05)$ compared to the percentage of cell viability exhibited by untreated cells, respectively.

\subsection{Selectivity Index (SI)}

Both compounds showedgood selectivity against HT-29 and CCD-18Co cell lines with the SI value of more than 2 (Table 1). High SI value $(>2)$ of a compound gives a selective toxicity towards cancer cells. While the compound with SI value $<2$ is considered to give general toxicity in which it also can cause cytotoxicity in normal cells (Badisa et al., 2009).

\subsection{Morphological Changes of HT-29 Cells Induced by Triphenyltin (IV) $\mathrm{N}$-alkyl- $\mathrm{N}$ - Phenyldithiocarbamate}

The observation of cells morphology changes were assesed using the different concentration of compounds upon $24 \mathrm{~h}$ treatment (Fig. 5). The result of observation showed that the cells were treated using the highest concentration up to $2 \mu \mathrm{M}$, the cell become shrink and formation of apoptotic bodies whereas no significant difference with the untreated cells when the cells were exposed to the lowest concentration $0.031 \mu \mathrm{M}$.

\subsubsection{Mode of Cell Death on HT-29 Cells Upon Treated with Triphenyltin (IV) $\mathrm{N}$-alkyl- $\mathrm{N}$ - Phenyldithiocarbamate}

The percentage of the externalization of phosphatidylserine in HT-29 cells, treated with $\mathrm{IC}_{50}$ concentration of both compounds showed that the percentage of cells died via apoptosis were less than $10 \%$, whereby the total cell death were less than $12 \%$ (Fig. 6). The cells were mainly viable and there was no significant difference among the percentage of live cells in treated and untreated cells. 
Table 1. Selectivity Index (SI) for compound 1 and compound 2

\begin{tabular}{lll}
\hline & Compound 1 & Compound 2 \\
\hline $\mathrm{IC}_{50}$, CCD-18Co & $1.55 \mu \mathrm{M}$ & $>2.00 \mu \mathrm{M}$ \\
$\mathrm{IC}_{50}$, HT-29 & $0.18 \mu \mathrm{M}$ & $0.20 \mu \mathrm{M}$ \\
$\mathrm{SI}$ & 8.61 & $>10$ \\
\hline
\end{tabular}

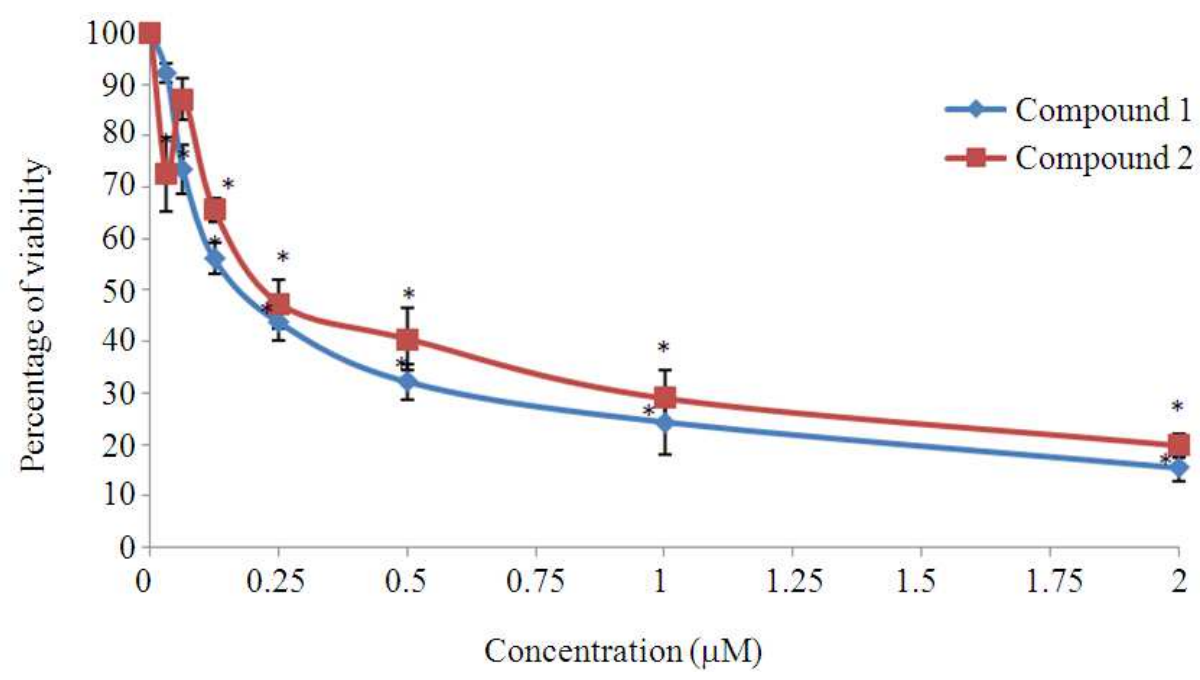

Fig. 3. The cytotoxicity of compound 1 and 2against HT-29 cells upon $24 \mathrm{~h}$ of treatment using MTT assay. Data represent the mean $( \pm$ SEM) of at least three independent experiments

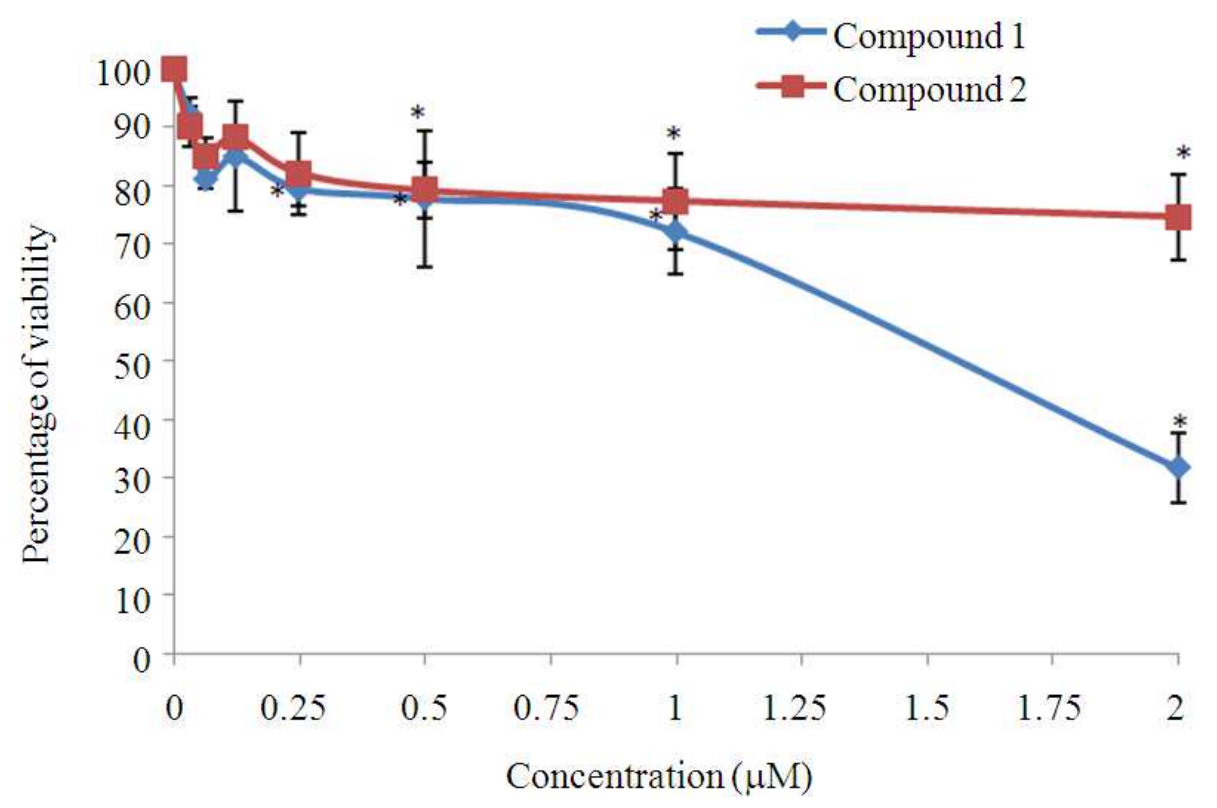

Fig. 4. The cytotoxicity of compound 1 and 2 against $\mathrm{CCD}-18^{\circ} \mathrm{C}$ cells upon $24 \mathrm{~h}$ of treatment using MTT assay. Data represent the mean $( \pm \mathrm{SEM})$ of at least three independent experiments 


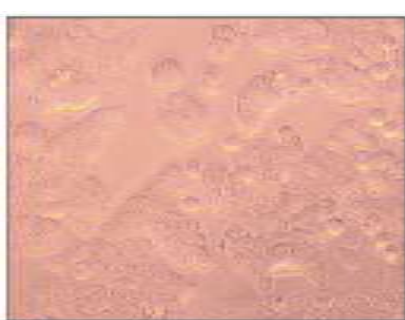

(a)

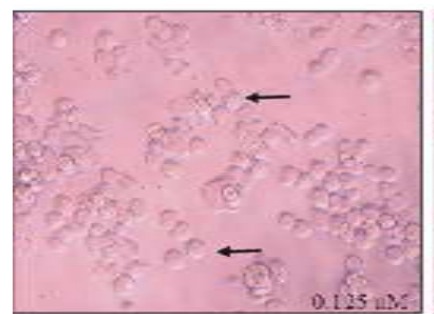

(d)

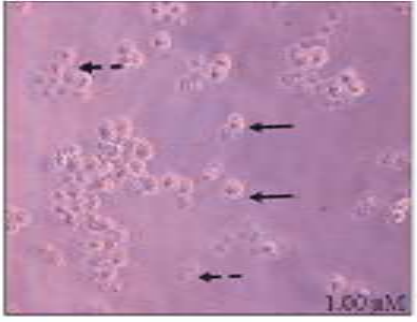

(g)

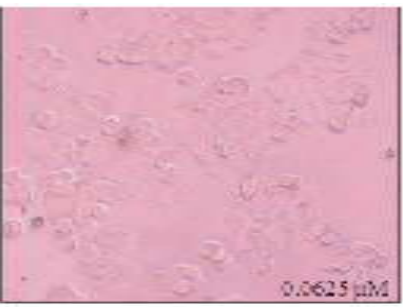

(j)

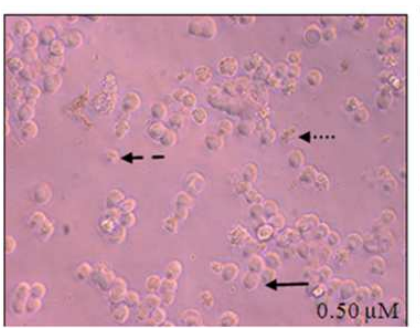

(m)

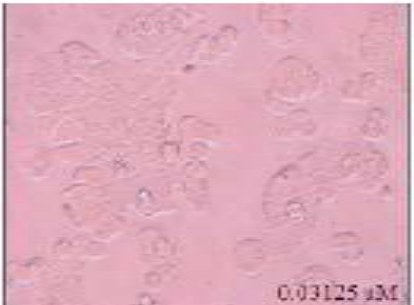

(b)

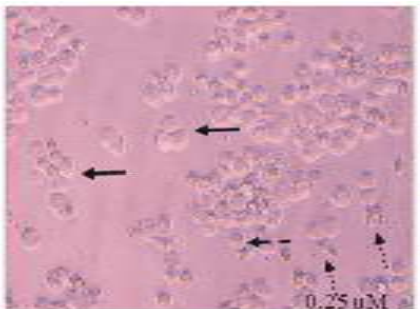

(e)

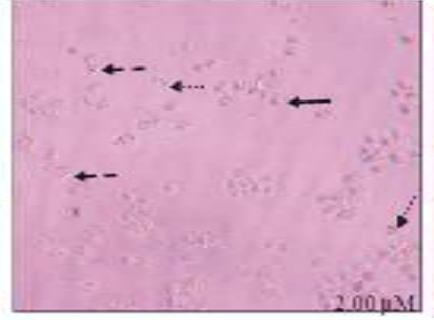

(h)

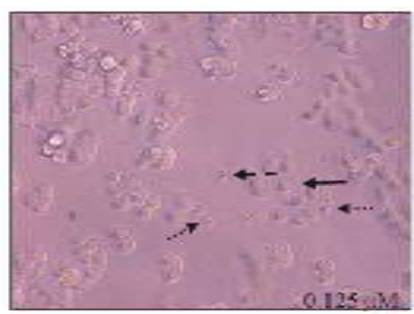

(k)

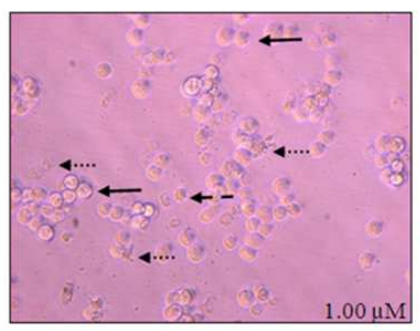

(n)

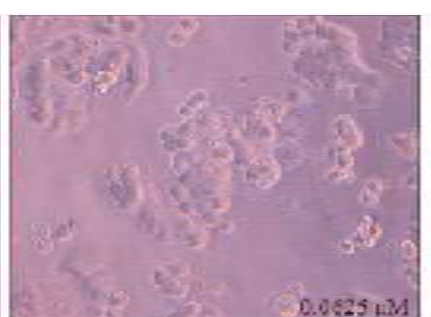

(c)

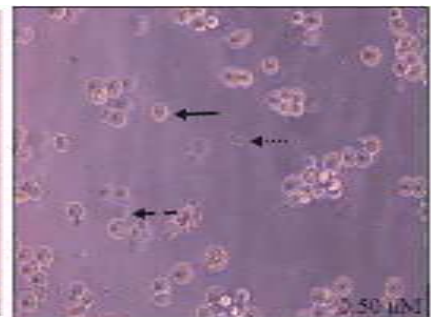

(f)

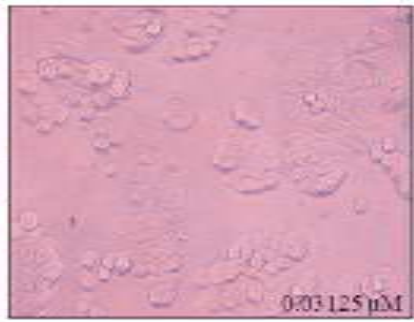

(i)

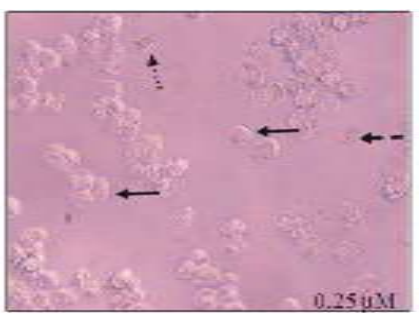

(1)

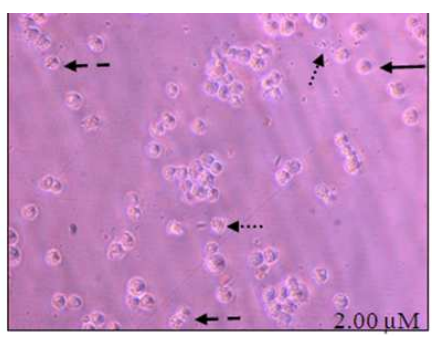

(o)

Fig. 5. Morphological observations of HT-29 cells upon 24 h of treatment of compound 1 (b-h) and compound 2 (i-o) using 7 different concentrations at $20 \mathrm{X}$ magnification. (a) Represents the untreated cells. Both compounds induced morphological changes in HT-29 cells. The morphological changes that can be observed included cell shrinkage, cells became rounded and cells lysis 


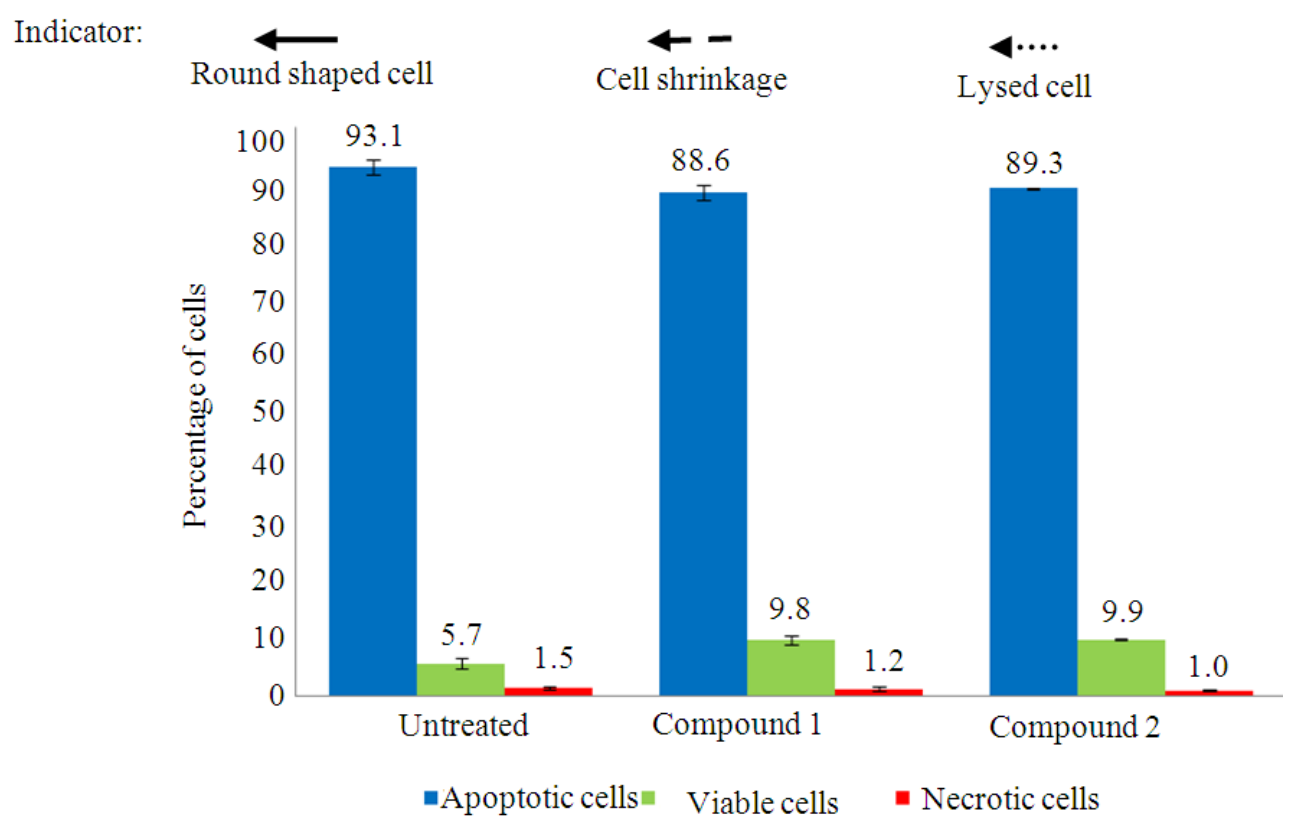

Fig. 6. The percentage of viable, apoptotic and necrotic cells in HT-29 cells upon treated with compound 1 and 2 at $\mathrm{IC}_{50}$ concentration for $24 \mathrm{~h}$. Data represent the mean $( \pm$ SEM) of at least three independent experiments

\section{DISCUSSION}

The organotin derivatives are greatly being synthesized and their anticancer properties are extensively being studied. Organotin compounds have shown a marked cytotoxicity in various types of cell lines of human and animal origins. Several organotin compounds synthesized by our group also showed significant cytotoxicity towards HepG2 hepatocarcinoma, Jurkat $\mathrm{T}$ lymphoblastic, chronic myelogenous leukemia (K562) and thymoma murine (WEHI 7.2) cell lines (Kamaludin et al., 2013). Previous finding showed that organotin (IV) dithiocarbamate compounds displayed high toxicity towards Jurkat T lymphoblastic and K562 cells with $\mathrm{IC}_{50}$ values of less than $9.2 \mu \mathrm{M}$ (Kamaludin et al., 2013). Therefore, they were classified as very toxic compounds (How et al., 2008).

Similarly, the triphenyltin (IV) $N$-alkyl- $N$ phenyldithiocarbamate compounds could also be classified as very toxic due to their efficacy to inhibit the growth of HT-29 cell's population as low as 0.18 $\mu \mathrm{M}$. However, in CCD-18Co cells, high cytotoxicity was only given by compound 1 with $\mathrm{IC}_{50}$ value of 1.55 $\mu \mathrm{M}$. Compound 2 was expected to give median inhibitory concentration above $2.00 \mu \mathrm{M}$. Both compounds gave cytotoxicity in HT-29 and CCD-18Co cells whereby the higher cytotoxicity was reported by compound 1. This study suggested that the molecular structure of a compound plays a significant role in determining its cytotoxicity. The shorter length of alkyl substitution group in a compound increases its cytotoxicity (Biplob et al., 2008; Ray et al., 2000). This probably explained our finding that showed higher cytotoxicity of compound with ethyl group compared to butyl group in dithiocarbamate ligand, respectively.

Due to the different cytotoxicity exerted by both compounds, the Selectivity Index (SI) was measured to determine their selectivity property (Machana et al., 2011; Badisa et al., 2009). Both compounds had good selectivity against cancer cells with the SI values higher than 2 . However, the SI value of compound 2 was greater than compound 1 . This indicated that compound 2 probably more suitable to be further studied as a potent anticancer drug.

To further evaluated the cell changes upon treatment, the cell morphological observation was conducted in HT-29 cells. The morphological changes of the cells were detected to be varied in concentration-dependent manner. Slight morphological changes were found at $0.03125 \mu \mathrm{M}$ and $0.0625 \mu \mathrm{M}$. Whilst, at $0.125 \mu \mathrm{M}$ concentration, the cells began to appear in visibly different form as 
compared to control. The cells started losing their shape with more intercell spaces were observed.Gradually, with the increment of treatment concentrations, the cells changed to round shaped cells and getting smaller in size or shrinked. At 2.00 $\mu \mathrm{M}$ concentration, dead cells floated and dirty background were observed suggesting the cells lysed.Cell shrinkage resembles the apoptotic characteristic (Pellerito et al., 2006), thus we suggested that the cells died via apoptosis.

To further confirm the mode of cell death, the Annexin V-FITC/PI test was conducted to determine the percentage of the cells death, either through apoptosis or necrosis. Apoptotic cell death is accompanied by the translocation of Phosphatidylserine (PS) from inner to the outer part of the plasma membrane thereby exposing PS to the external cellular activity (Alabsi et al., 2012). The binding ability of Annexin $\mathrm{V}$ to plasma membrane containing PS in the presence of calcium ion $\left(\mathrm{Ca}^{2+}\right)$ indicates that the cells died via apoptosis (Engeland et al., 1998).

In this study, both compounds gave only small percentage of cells death which were less than $12 \%$ of overall cell death after treated with $\mathrm{IC}_{50}$ values of both compounds within $24 \mathrm{~h}$. These results displayed inconsistent trend with the $\mathrm{IC}_{50}$ values obtained from the MTT assay. More than $80 \%$ of cells were detected as viable in Annexin V-FITC/PI assay as compared to the $50 \%$ cells viability as expected from MTT assay results. Hence, these data demonstrated that the different endpoints being assessed by two different methods would greatly influence the experimental data (Chan et al., 2006). The measurement of cell viability using MTT assay is based on reduction of tetrazholium salt by the mitochondrial succinate dehydrogenase enzyme to form crystal formazan, while the measurement of cell death in Annexin V-FITC/PI method is dependent on the integrity of plasma membrane (Mosmann, 1983; Engeland et al., 1998).

Based on the mode of cell death assessment, this study suggested that the cytotoxic effects exerted by these compounds were not by directly killing the cells, but most probably due to the growth inhibitory effects of HT-29 cells at the cell cycle level. Within this cycle, there is a phase known as $G_{0}$ phase whereby no proliferation occurs in living cells and the cells will leave the cycle temporarily (Pratt, 1994). This could be the possible reason to the observation made in this study whereby the HT-29 cells were still alive upon treated with $\mathrm{IC}_{50}$ concentration, which could be due to the cells were in resting phase. Hence, the percentages of dead cells were less than $50 \%$ in HT-29 cells treated with $\mathrm{IC}_{50}$ concentration of both compounds, suggesting that both compounds might act through the inhibition of cell proliferation instead of killing the cells.

\section{CONCLUSION}

The triphenyltin (IV) $\quad N$-alkyl- $N$ phenyldithiocarbamate compounds demonstrated a strong cytotoxicity in HT-29 cells and showed good selectivity between HT-29 and CCD-18Co cells. In comparison between these compounds, the triphenyltin (IV) butylphenyldithiocarbamate (compound 2) was found to be more selective on cancer cells than triphenyltin (IV) ethylphenyldithiocarbamate (compound 1). However, the efficacy of both compounds to kill the HT-29 cells were not as expected whereby more than $80 \%$ of cells were remain viable upon treated using the $\mathrm{IC}_{50}$ concentration. Hence, this study suggested that both compounds induced growth arrest in HT-29 cells due to the lower percentage of apoptotic cell death.

\section{ACKNOWLEDGMENT}

We would like to thank Universiti Kebangsaan Malaysia for the GUP-2012-021 grant and the laboratory assistants of Biomedical Science Programme and Environmental Health and Industrial Safety Programme, Faculty of Health Sciences, Universiti Kebangsaan Malaysia for the technical support.

\section{REFERENCES}

Abdellah, M.A., S.K. Hadjikakou, N. Hadjiliadis, M. Kubicki and T. Bakas et al., 2009. Synthesis, characterization and biological studies of organotin (IV) derivatives with o-or p-hydroxybenzoic acids. Bioinorganic Chem. Applic. DOI: $10.1155 / 2009 / 542979$

ACS, 2013. Colorectal cancer.

Alabsi, A.M., R. Ali, A.M. Ali, S.A.R. Al-Dubai and H. Harun et al., 2012. Apoptosis induction, cell cycle arrest and in vitro anticancer activity of gonothalamin in a cancer cell lines. Asian Pasific J. Cancer Prevent., 13: 5131-5136. DOI: 10.7314/APJCP.2012.13.10.5131 
Alama, A., B. Tasso, F. Novelli and F. Sparatore, 2009. Organometallic compounds in oncology: Implications of novel organotins as anticancer agents. Drug Discovery Today, 14: 500-508. DOI: 10.1016/j.drudis.2009.02.002

Badisa, R.B., S.F. Darling-Reed, P. Joseph, J.S. Cooperwood and L.M. Latinwo et al., 2009. Selective cytotoxic activities of two novel synthetic drugs on human breast carcinoma MCF7 Cells. Anticancer Res., 29: 2993-2996. PMID: 19661306

Biplob, K., T.S.B. Baul and A. Chatterjee, 2008. p53dependent antiproliferative and anticancer effect of novel alkyl series of diorganotin (IV) compounds. Invest New Drugs, 27: 319-326. DOI: $\quad 10.1007 / \mathrm{s} 10637-008-9176-6, \quad$ PMID: 18802665

Chan, K.M., N.F. Rajab, M.H.A. Ishak, A.M. Ali and K. Yusoff et al., 2006. Goniothalamin induces apoptosis in vascular smooth muscle cells. Chemico-Biolog. Interact., 159: 129-140. DOI: 10.1016/j.cbi.2005.10.107

Chan, K.M., R. Hamzah, A.A. Rahaman, V.Y.M. Jong and H.Y. Khong et al., 2012. The pyranoxanthone inophyllin A induces oxidative stress mediatedapoptosis in Jurkat $\mathrm{T}$ lymphoblastic leukemia cells. Food Chem. Toxicol., 50: 2916-2922. DOI: 10.1016/j.fct.2012.04.048

Engeland, M .V., L.J.W. Nieland, F.C.S. Ramaekers, B. Schuttle and C.P.M. Reutelingsperger, 1998. Annexin V-affinity assay: A review on an apoptosis detection system based on phosphatidylserine exposure. Cytometry, 31: 1-9. DOI: 10.1002/(SICI)10970320(19980101)31:1<1::AID-CYTO1>3.0.CO;2-R

Gielen, M., M. Biesemans, D. Vos and R. Willem, 2000. Synthesis, characterization and in vitro anticancer activity of di-and triorgaotin derivatives of polyoxa- and biologically relevant carboxylic acids. J. Inorganic Biochem., 79: 139145. DOI: 10.1016/S0162-0134(99)00161-0

Girasolo, M.A., S. Rubino, P. Portanova, G. Calvaruso and G. Ruisi et al., 2010. New organotin (IV) complexes with L-Arginine, $\mathrm{Na}$ - $\mathrm{t}$ Boc-L-Arginine and L-Alanyl-L-Arginine: Synthesis, structural investigations and cytotoxic activity. J. Organometallic Chem., 695: 609-618. DOI: $10.1016 /$ j.jorganchem.2009.11.002
Hagan, S., M.C.M. Orr and B. Doyle, 2013. Targeted therapies in colorectal cancer-an integrative view by PPPM. EPMA J., 4: 1-16. DOI: DOI:10.1186/1878-5085-4-3

How, F.N.F., K.A. Crouse, M.I.M. Tahir, M.T.H Tarafder and A.R. Cowley et al., 2008. Synthesis, characterization and biological studies of Sbenzyl- $\beta-N$-(benzoyl) dithiocarbazate and its metal complexes. Polyhedron, 27: 3325-2229. DOI: $10.1016 /$ j.poly.2008.07.022

Kamaludin, N.F., I. Baba, N. Awang, M.I.M. Tahir and E.R.T. Tiekink, 2012. ( $N$ - Ethyl- $N$ enyldithiocarbamato- $\mathrm{K}$ ) triphenyltin (IV). Acta Cryst. E, 68: 62-63. DOI: 10.1107/S1600536811053591

Kamaludin, N.F., I. Baba, N. Awang, M.I.M. Tahir and E.R.T. Tiekink, 2011. ( $N-$ Butyl- $N-$ phenyldithiocarbamato- $\mathrm{K}$ ) triphenyltin (IV). Acta Cryst. E, 67: 555-556. DOI: $10.1107 / \mathrm{S} 1600536811012426$

Kamaludin, N.F., N. Awang, I. Baba, A. Hamid and K.M. Chan, 2013. Synthesis, characterization and crystal structure of organotin (IV) N-butyl-Nphenyldithiocarbamate compounds and their cytotoxicity in human leukemia cell lines. Pak. J. Biol. Sci., 16: 12-21. PMID: 24199481

Machana, S., N. Weerapreeyakul, S. Barusrux, A. Nonpunya and B. Sripanidkulchai et al., 2011. Cytotoxic and apoptotic effects of six herbal plants against the human hepatocarcinoma (HepG2) cell line. Chinese Med., 6: 39-39. DOI: 10.1186/1749-8546-6-39

Mosmann, T., 1983. Rapid colorometric assay for cellular growth and survival: Application to proliferation and cytotoxicity assay. J. Immunol. Meth., 65: 55-63. DOI: 10.1016/0022-1759(83)90303-4

Oliveira, N.D., K.V. Andermark, S.V. Grafenstein, L.A. Onambele and G. Dahl et al., 2013. Butyltin (IV) benzoates: Inhibition of thioredoxin reductase, tumor cell growth inhibition and interactions with proteins. Chem. Med. Chem., 8: 256-264. DOI: $10.1002 / \mathrm{cmdc} .201200505$

NCI, 2013. Drugs approved for colon and rectal cancer. National Cancer Institute,

Pellerito, C., L. Nagy, L. Pellerito and A. Szorcsik, 2006. Biological activity studies on organotin $(\mathrm{IV})^{n+}$ complexes and parent compounds. J. Organometallic Chem., 691: 11733-1747. DOI: 10.1016/j.jorganchem.2005.12.025 
Pratt, W.B., 1994. The Anticancer Drugs. 2nd Edn., Oxford University Press, USA. ISBN ISBN-10: 0195067398, pp: 360

Ray, D., K.D. Sarma and A. Antony, 2000. Differential effects of tri-n-butylstannyl benzoates on induction of apoptosis in K562 and MCF-7 cells. IUMBM Life, 49: 519-525. DOI: 10.1080/15216540050167061

Sasaki, K., N.H. Tsuno, E. Sunami, G. Tsurita and K. Kawai et al., 2010. Choloqiune potentiates the anti-cancer effect of 5-fluorouracil on colon cancer cells. BMC Cancer, 10: 370-390. DOI: 10.1186/1471-2407-10-370

Shahzadi, S., S. Ali, M.H. Bhatti, M. Fettouchi and M. Athar, 2006. Chloro-diorganotin (IV) complexes of 4-methyl-1-piperidine carbodithioic acid: Synthesis, x-ray crystal structures, spectal properties and antimicrobial studies. J. Organometallic Chem., 691: 1797-1802. DOI: 10.1016/j.jorganchem.2005.12.004

Srimuangwong, K., C. Tocharus, P.Y. Chintana, A.
Suksamrarn and J. Tocharus, 2012. Hexahydrocurcumin enhances inhibitory effect of 5-fluorouracil on HT29 human colon cancer cells. World J. Gastroenterol, 18: 2383-2389. DOI: 10.3748/wjg.v18.i19.2383, PMID: 22654430

Thati, B., A. Noble, B.S. Creaven, M. Walsh and M. McCann et al., 2007. In vitro anti-tumour and cytoselective effects of coumarin-3-carboxylic acid and three of its hydroxylated derivatives, along with their silver-based complexes, using human epithelial carcinoma cell lines. Cancer Lett., 248: 321-331. DOI: :10.1016/j.canlet.2006.08.009

Tong, J., G. Xie, J. He, J. Li and F. Pan et al., 2011. Synergistic anticancer effect of dichloroacetate in combination with 5-fluorouracil in colorectal cancer. J. Biomed. Biotechnol. DOI: 10.1155/2011/7405, PMID: 21403907 